\title{
ACUTE TOXICITY OF B-KITIN EXTRACTED FROM THE SHELL OF BLUE SWIMMING CRAB (PORTUNUS PELAGICUS LINN.)
}

\author{
RENNY AMELIA $^{1,2^{*}}$, NYI MEKAR SAPTARINI ${ }^{3}$, JUTTI LEVITA ${ }^{1}$, SRI ADI SUMIWI ${ }^{1}$
}

${ }^{1}$ Department of Pharmacology and Clinical Pharmacy, Universitas Padjadjaran, Sumedang 45363, (West Java) Indonesia, ${ }^{2}$ Department of Pharmacology, School of Pharmacy Muhammadiyah Cirebon, Cirebon-45153, (West Java) Indonesia, ${ }^{3}$ Department of Pharmaceutical Analysis and Medicinal Chemistry, Universitas Padjadjaran, Sumedang 45363, (West Java) Indonesia Email: rennyamelia@stfmuhammadiyahcirebon.ac.id

Received: 08 Aug 2021, Revised and Accepted: 15 Aug 2021

\section{ABSTRACT}

Objective: This work aimed to study the acute toxicity of $\beta$-chitin extracted from crab shells in Bal b/c mice.

Method: The acute toxicity test was performed by following the OECD guidelines. Female mice were given single or divided doses of $\beta$-chitin (maximum $24 \mathrm{~h}$ ) with doses of 500,1000, 2000, 4000, and $6000 \mathrm{mg} / \mathrm{kg}$ of BW. Observations were made for $14 \mathrm{~d}$, including behaviour, body weight, organ weight, and histopathology of vital organs (stomach, heart, liver, kidney, and lung).

Results: During 14 d, no deaths and no abnormalities in behaviour, bodyweight or organ weight were observed. Qualitative histopathological observations at the highest dose showed abnormalities of the liver and kidney compared to those of the control group. Nevertheless, the abnormalities did not affect the organ function.

Conclusion: This acute toxicity study reveals that $\beta$-chitin up to a dose of $6000 \mathrm{mg} / \mathrm{kg}$ of BW is not toxic, as proved by the normal behaviour, body weight, and vital organ weight of the animals. Further chronic toxicities study is needed to confirm its safety.

Keywords: $\beta$-chitin, Crab, Acute toxicity, Histopathology

(C) 2021 The Authors. Published by Innovare Academic Sciences Pvt Ltd. Thisis an open access article under the CC BYlicense (https://creativecommons.org/licenses/by/4.0/) DOI: https://dx.doi.org/10.22159/ijap.2021.v13s4.43843 Journal homepage: https://innovareacademics.in/journals/index.php/ijap

\section{INTRODUCTION}

Chitin is a polysaccharide that is commonly found as a constituent of crustacean shells. Chitin activity has been investigated in various studies, including as anti-tumor [1], anti-cancer [2], anti-inflammatory [3], and to prevent gastric ulcers [4]. Blue swimming crab, as one of the chitinproducing crustacean groups, generally produces polymorphic $\alpha$-forms [5]. By extracting twice using NADES solvent, crabs can produce chitin in the form [6]. Compared to the $\alpha$-form, $\beta$-chitin can swell better in water, alcohol and alcohol amines [7]. There is not much literature regarding the activity of $\beta$-chitin. However, $\beta$-chitin hydrogel together with nanosilver and nano $\mathrm{ZnO}$, which are formulated in the form of wound dressings or bandages, have advantages such as blood clotting ability, antibacterial activity, and can heal wounds in rats faster so that they have the potential for wound healing [8-9]. Feeding chitin up to $5 \%$ of the total diet for $13 \mathrm{w}$ did not show any mortality in mice; however, the histopathological results for the five main organs were not yet available [10]. Thus, this work studied the acute toxicity of $\beta$-chitin with observations including body weight and histopathology of the heart, stomach, lungs, liver and kidneys.

\section{MATERIALS AND METHODS}

\section{Materials}

Microwave oven Rewez multifunction, sentrifuge (80-1 table top low speed centrifuge), Blue swimming crab shell originated from Gunung Jati Cirebon with size ranges $13-15 \mathrm{~cm}$, Choline chloride (Salus Nutra Inc), DL-malic acid (Salus Nutra Inc). Mice (Balb/c) strains aged 5-6 w weighing 20-24 grams were obtained from Bos Tikus Animal Center for Research, Surakarta, Indonesia. This study has obtained approval from the animal ethics committee with number 541/UN6. KEP/EC/2020. Histopathological observations using an Olympus CX33 microscope and ImageJ software.

\section{Methods}

\section{$\beta$-chitin extraction}

Blue swimming crab shell powder (mesh-60) was homogenized with NADES (1:20). NADES consists of choline chloride and DL-malic acid $(1: 1)$ molar ratio. The mixture was heated in the microwave at $700 \mathrm{w}$ for $9 \mathrm{~min}$. To reduce excess heat, it was taken out from the microwave every minute for $3 \mathrm{sec}$. NADES were separated by centrifugation and the precipitate was taken and then washed with distilled water [11]. $\beta$ chitin was obtained by re-extracted using the same procedure [6].

\section{Acute toxicity}

Mice were adapted for seven days with a day-night cycle of $12 \mathrm{~h}$ each. After acclimatization, mice were divided into $\beta$-chitin dose groups of 500, 1000, 2000, 4000 and $6000 \mathrm{mg} / \mathrm{kg}$ BW and control. Each group consisted of 5 female mice (according to Frederer's formula) with an even distribution of bodyweight not exceeding $20 \%$ of the average body weight [12]. Mice fasted for $3 \mathrm{~h}$ while still being given access to drink. Samples were given to mice orally in one administration or no more than $24 \mathrm{~h}$ if repeated. Observations were made for $14 \mathrm{~d}$ covering animal behaviour and body weight.

\section{Observation parameters}

Observations of test animals were carried out continuously for the first $30 \mathrm{~min}$ after administration of the preparation. Observations were continued every $4 \mathrm{~h}$ for $24 \mathrm{~h}$. After $24 \mathrm{~h}$, observations were made every day for $14 \mathrm{~d}$. Observations included changes in skin and coat color, eyes and backward walking behavior. In addition, the animals also observed tremor, convulsion, salivation, diarrhea, lethargy, sleep, coma and mortality. Each parameter observed will be compared with the control group (Na. CMC 2\%) [13]. Bodyweight of mice was weighed on day one and day 14 to see the effect of $\beta$ chitin administration on body weight.

\section{Histopathology}

Each group used three mice to take vital organs as samples for histopathological analysis. The test was carried out at the Animal Biosystem Laboratory, Department of Biology, Padjadjaran University using the HE (hematoxylin-eosin) staining technique. The test organs include the stomach, heart, liver, kidneys and lungs. Quantitative observations of each organ included the number of normal cells, necrosis and apoptosis. Qualitative observations had hydropic degeneration, fat degeneration, inflammatory cell infiltration, bleeding. In addition, additional observations of the 
glomerulus and Bowman's capsule in the kidney, central vein and sinusoid observations in the liver. In qualitative observations, scoring is carried out to be calculated quantitatively [14].

\section{$0=$ Normal \\ $1=$ Focal \\ $2=$ Diffuse}

Histopathology scoring

\section{Centralis vein scoring}

$0=$ Normal

$1=$ Lesion

Sinusoid scoring

$0=$ Normal

$1=$ Dilatation

Glomerulus scoring

$0=$ Normal

$1=$ Atrophy

\section{Analysis}

The results were analyzed using SPSS.24 software. All data were tested for normality and continued with a significance difference test. The Wilcoxon test analyzed the follow-up test of mice's body weight on the first and last days of observation. The analysis was carried out by comparing the relative organ weight percentage given to the sample with the control to see the effect of $\beta$-chitin administration on organ weight. In addition, the analysis of relative organ weight percentage and histology were analyzed using a twoway independent test if the data were normal and the MannWhitney test if the data was not normal. The following formula calculates the percentage of organ weight:

$$
\text { Relative organ weight percentage }=\left(\frac{\text { organ weight }}{\text { Bodyweight }}\right) \times 100 \%
$$

\section{RESULTS}

Toxicity is one of the safety parameters that must be known if a substance is used in daily life. The first type of safety testing performed is the acute toxicity test. Acute toxicity will evaluate the side effects of a substance that will occur when an organism is exposed to a single dose or divided doses for $24 \mathrm{~h}$ via a known route of administration, for example, orally.

Table 1: Body weight of mice before and on the $14^{\text {th }}$ day after administration of $\beta$-chitin $(n=5)$

\begin{tabular}{llll}
\hline Group (mg/kg BW) & BW D_1 (g) & BW D_14 (g) & Increase in Weight \\
\hline 500 & $20.00 \pm 0.00$ & $22.30 \pm 1.37^{*}$ & $2.29 \pm 1.23$ \\
1000 & $20.40 \pm 0.55$ & $23.00 \pm 0.57^{*}$ & $2.56 \pm 0.93$ \\
2000 & $21.00 \pm 0.00$ & $23.50 \pm 1.03^{*}$ & $2.49 \pm 0.92$ \\
4000 & $22.00 \pm 0.00$ & $22.62 \pm 1.81^{*}$ & $0.62 \pm 1.62^{\#}$ \\
6000 & $23.00 \pm 0.00$ & $26.48 \pm 1.12^{*}$ & $3.48 \pm 1.00$ \\
Control & $23.40 \pm 1.34$ & $26.14 \pm 2.39^{*}$ & $2.74 \pm 2.18$ \\
\hline
\end{tabular}

${ }^{*}$ p value $<0.05$ vs $1^{\text {st }}$ day body weight per dose group; \#p value $<0.05$ vs control

Table 2: Relative organ weight (\%) $(n=5)$

\begin{tabular}{lllll}
\hline Group (mg/kg BW) & \multicolumn{2}{l}{} & \\
\cline { 2 - 5 } & Selative organ weight (\%) & Liver & Kidney \\
\hline 500 & $1.13 \pm 0.04$ & $0.52 \pm 0.09$ & $5.45 \pm 0.65$ & $1.51 \pm 0.24$ \\
1000 & $1.11 \pm 0.11$ & $0.52 \pm 0.10$ & $6.33 \pm 0.84$ & $1.47 \pm 0.11$ \\
2000 & $1.26 \pm 0.11$ & $0.50 \pm 0.10$ & $5.33 \pm 0.58$ & $1.43 \pm 0.15$ \\
4000 & $1.23 \pm 0.17$ & $0.50 \pm 0.04$ & $6.01 \pm 0.69$ & $1.00 \pm 0.20$ \\
6000 & $1.21 \pm 0.16$ & $0.46 \pm 0.05$ & $5.62 \pm 0.81$ & $1.39 \pm 0.12$ \\
Control & $1.23 \pm 0.10$ & $0.49 \pm 0.07$ & $6.16 \pm 1.43$ & $1.50 \pm 0.16$ \\
\hline
\end{tabular}

${ }^{*}$ p value $<0.05$ vs control

Table 3: Quantitative and qualitative of heart, gastric, and lung histopathology $(n=3)$

\begin{tabular}{|c|c|c|c|c|c|c|c|}
\hline \multirow[t]{2}{*}{ Group } & \multicolumn{3}{|c|}{ Quantitative test } & \multicolumn{4}{|l|}{ Qualitative test } \\
\hline & Normal cell & Necrosis & Apoptosis & $\begin{array}{l}\text { Hydropic } \\
\text { degeneration }\end{array}$ & $\begin{array}{l}\text { Fatty } \\
\text { degeneration }\end{array}$ & $\begin{array}{l}\text { Inflammatory cell } \\
\text { infiltration }\end{array}$ & Bleeding \\
\hline \multicolumn{8}{|l|}{ HEART } \\
\hline 500 & $924.33 \pm 2.49$ & $32.67 \pm 2.87$ & $43.00 \pm 0.82$ & $1.00 \pm 0.00$ & $1.00 \pm 0.00$ & $1.00 \pm 0.00$ & $1.00 \pm 0.00$ \\
\hline 1000 & $928.33 \pm 3.09$ & $32.00 \pm 1.41$ & $39.67 \pm 1.70$ & $1.00 \pm 0.00$ & $1.00 \pm 0.00$ & $1.00 \pm 0.00$ & $1.00 \pm 0.00$ \\
\hline 2000 & $921.33 \pm 2.05$ & $36.00 \pm 1.63$ & $42.67 \pm 2.05$ & $1.00 \pm 0.00$ & $1.00 \pm 0.00$ & $1.00 \pm 0.00$ & $1.00 \pm 0.00$ \\
\hline 4000 & $912.67 \pm 1.70$ & $40.00 \pm 1.63^{*}$ & $47.33 \pm 2.62$ & $1.00 \pm 0.00$ & $1.00 \pm 0.00$ & $1.00 \pm 0.00$ & $1.00 \pm 0.00$ \\
\hline 6000 & $907.00 \pm 6.16$ & $44.00 \pm 2.45^{*}$ & $49.00 \pm 3.74$ & $1.33 \pm 0.47$ & $1.33 \pm 0.47$ & $1.00 \pm 0.00$ & $1.67 \pm 0.47$ \\
\hline $\begin{array}{l}\text { Control } \\
\text { STOMACH }\end{array}$ & $920.67 \pm 5.79$ & $32.33 \pm 2.62$ & $47.00 \pm 3.74$ & $1.00 \pm 0.00$ & $1.00 \pm 0.00$ & $1.00 \pm 0.00$ & $1.00 \pm 0.00$ \\
\hline 500 & $925.00 \pm 2.45^{*}$ & $33.00 \pm 2.45$ & $42.00 \pm 2.45$ & $1.00 \pm 0.00$ & $1.00 \pm 0.00$ & $1.00 \pm 0.00$ & $1.00 \pm 0.00$ \\
\hline 1000 & $922.33 \pm 2.05^{*}$ & $39.00 \pm 0.82$ & $38.67 \pm 1.25^{*}$ & $1.00 \pm 0.00$ & $1.00 \pm 0.00$ & $1.00 \pm 0.00$ & $1.00 \pm 0.00$ \\
\hline 2000 & $921.67 \pm 2.05$ & $42.33 \pm 2.49$ & $36.00 \pm 2.45^{*}$ & $1.00 \pm 0.00$ & $1.00 \pm 0.00$ & $1.00 \pm 0.00$ & $1.00 \pm 0.00$ \\
\hline 4000 & $913.00 \pm 2.45$ & $49.33 \pm 1.89 *$ & $37.67 \pm 1.25^{*}$ & $1.00 \pm 0.00$ & $1.00 \pm 0.00$ & $1.00 \pm 0.00$ & $1.00 \pm 0.00$ \\
\hline 6000 & $897.00 \pm 2.16^{*}$ & $57.67 \pm 3.40^{*}$ & $45.33 \pm 1.25$ & $1.67 \pm 0.47$ & $1.67 \pm 0.47$ & $1.33 \pm 0.47$ & $1.67 \pm 0.47$ \\
\hline Control & $918.00 \pm 1.41$ & $37.67 \pm 2.49$ & $44.33 \pm 1.25$ & $1.00 \pm 0.00$ & $1.00 \pm 0.00$ & $1.00 \pm 0.00$ & $1.00 \pm 0.00$ \\
\hline LUNG & & & & & & & \\
\hline 500 & $924.67 \pm 3.68$ & $35.67 \pm 1.70$ & $39.67 \pm 2.62$ & $1.00 \pm 0.00$ & $1.00 \pm 0.00$ & $1.00 \pm 0.00$ & $1.00 \pm 0.00$ \\
\hline 1000 & $914.33 \pm 2.05^{*}$ & $41.67 \pm 2.05$ & $44.00 \pm 2.45$ & $1.00 \pm 0.00$ & $1.00 \pm 0.00$ & $1.00 \pm 0.00$ & $1.00 \pm 0.00$ \\
\hline 2000 & $913.00 \pm 0.82 *$ & $45.00 \pm 2.45^{*}$ & $42.00 \pm 1.63$ & $1.00 \pm 0.00$ & $1.00 \pm 0.00$ & $1.00 \pm 0.00$ & $1.00 \pm 0.00$ \\
\hline 4000 & $909.33 \pm 4.03^{*}$ & $46.33 \pm 2.49 *$ & $44.33 \pm 1.70 *$ & $1.00 \pm 0.00$ & $1.00 \pm 0.00$ & $1.00 \pm 0.00$ & $1.00 \pm 0.00$ \\
\hline 6000 & $900.33 \pm 3.40^{*}$ & $53.67 \pm 1.25^{*}$ & $46.00 \pm 2.16^{*}$ & $1.33 \pm 0.47$ & $1.33 \pm 0.47$ & $1.00 \pm 0.00$ & $1.67 \pm 0.47$ \\
\hline Control & $925.00 \pm 3.74$ & $36.00 \pm 2.45$ & $39.00 \pm 1.41$ & $1.00 \pm 0.00$ & $1.00 \pm 0.00$ & $1.00 \pm 0.00$ & $1.00 \pm 0.00$ \\
\hline
\end{tabular}

$*$ p value $<0.05$ vs control 
Table 4: Quantitative and qualitative of liver and kidney histopathology $(n=3)$

\begin{tabular}{|c|c|c|c|c|c|c|c|c|c|}
\hline \multirow[t]{2}{*}{ Group } & \multicolumn{3}{|c|}{ Quantitative test } & \multicolumn{6}{|c|}{ Qualitative test } \\
\hline & Normal cell & Necrosis & Apoptosis & $\begin{array}{l}\text { Hydropic } \\
\text { degeneration }\end{array}$ & $\begin{array}{l}\text { Fatty } \\
\text { degeneration }\end{array}$ & $\begin{array}{l}\text { Inflammatory } \\
\text { cell infiltration }\end{array}$ & $\begin{array}{l}\text { Central } \\
\text { vein }\end{array}$ & Sinusoid & Bleeding \\
\hline \multicolumn{10}{|l|}{ Liver } \\
\hline 500 & $885.67 \pm 1.25$ & $54.33 \pm 2.87$ & $60.00 \pm 1.63$ & $1.00 \pm 0.00$ & $1.00 \pm 0.00$ & $1.00 \pm 0.00$ & $0.00 \pm 0.00$ & $0.00 \pm 0.00$ & $1.00 \pm 0.00$ \\
\hline 1000 & $880.33 \pm 1.25$ & $61.33 \pm 4.64$ & $58.33 \pm 3.40$ & $1.00 \pm 0.00$ & $1.00 \pm 0.00$ & $1.00 \pm 0.00$ & $0.00 \pm 0.00$ & $0.00 \pm 0.00$ & $1.00 \pm 0.00$ \\
\hline 2000 & $881.00 \pm 3.56$ & $64.33 \pm 6.18$ & $54.67 \pm 5.31$ & $1.00 \pm 0.00$ & $1.00 \pm 0.00$ & $1.00 \pm 0.00$ & $0.00 \pm 0.00$ & $0.00 \pm 0.00$ & $1.00 \pm 0.00$ \\
\hline 4000 & $861.00 \pm 12.03$ & $81.67 \pm 5.79$ & $57.33 \pm 6.80$ & $1.33 \pm 0.47$ & $1.33 \pm 0.47$ & $1.00 \pm 0.00$ & $0.00 \pm 0.00$ & $0.00 \pm 0.00$ & $1.00 \pm 0.00$ \\
\hline 6000 & $851.67 \pm 7.59 *$ & $92.67 \pm 7.36^{*}$ & $55.67 \pm 2.62^{*}$ & $1.67 \pm 0.47$ & $1.33 \pm 0.47$ & $1.00 \pm 0.00$ & $0.33 \pm 0.47$ & $0.33 \pm 0.47$ & $1.00 \pm 0.00$ \\
\hline $\begin{array}{l}\text { Contr } \\
\text { ol } \\
\text { Kidney }\end{array}$ & $883.33 \pm 8.06$ & $48.33 \pm 5.31$ & $68.33 \pm 3.68$ & $1.00 \pm 0.00$ & $1.00 \pm 0.00$ & $1.00 \pm 0.00$ & $0.00 \pm 0.00$ & $0.00 \pm 0.00$ & $1.00 \pm 0.00$ \\
\hline Group & Normal cell & Necrosis & Apoptosis & $\begin{array}{l}\begin{array}{l}\text { Hydropic } \\
\text { degeneration }\end{array} \\
\end{array}$ & $\begin{array}{l}\text { Fatty } \\
\text { degeneration }\end{array}$ & $\begin{array}{l}\text { Inflammatory } \\
\text { cell infiltration }\end{array}$ & Glomerulus & $\begin{array}{l}\text { Bowman's } \\
\text { Capsule }\end{array}$ & Bleeding \\
\hline 500 & $904.00 \pm 4.97 *$ & $48.67 \pm 2.49^{*}$ & $47.33 \pm 2.87$ & $1.00 \pm 0.00$ & $1.00 \pm 0.00$ & $1.00 \pm 0.00$ & $0.00 \pm 0.00$ & $0.00 \pm 0.00$ & $1.00 \pm 0.00$ \\
\hline 1000 & $909.67 \pm 4.11$ & $49.67 \pm 7.13$ & $40.67 \pm 3.09$ & $1.00 \pm 0.00$ & $1.00 \pm 0.00$ & $1.00 \pm 0.00$ & $0.00 \pm 0.00$ & $0.00 \pm 0.00$ & $1.00 \pm 0.00$ \\
\hline 2000 & $903.00 \pm 6.98$ & $53.67 \pm 4.99 *$ & $43.33 \pm 2.05$ & $1.00 \pm 0.00$ & $1.00 \pm 0.00$ & $1.00 \pm 0.00$ & $0.00 \pm 0.00$ & $0.00 \pm 0.00$ & $1.00 \pm 0.00$ \\
\hline 4000 & $891.00 \pm 4.32^{*}$ & $63.33 \pm 2.87^{*}$ & $45.67 \pm 5.79$ & $1.00 \pm 0.00$ & $1.00 \pm 0.00$ & $1.00 \pm 0.00$ & $0.00 \pm 0.00$ & $0.00 \pm 0.00$ & $1.00 \pm 0.00$ \\
\hline 6000 & $886.00 \pm 1.41^{*}$ & $72.33 \pm 3.30^{*}$ & $41.67 \pm 2.05$ & $1.33 \pm 0.47$ & $1.00 \pm 0.00$ & $1.00 \pm 0.00$ & $0.33 \pm 0.47$ & $0.00 \pm 0.00$ & $1.33 \pm 0.47$ \\
\hline $\begin{array}{l}\text { Contr } \\
\text { ol }\end{array}$ & $914.33 \pm 1.25$ & $41.33 \pm 2.49$ & $44.33 \pm 2.62$ & $1.00 \pm 0.00$ & $1.00 \pm 0.00$ & $1.00 \pm 0.00$ & $0.00 \pm 0.00$ & $0.00 \pm 0.00$ & $1.00 \pm 0.00$ \\
\hline
\end{tabular}

${ }^{*}$ p value $<0.05$ vs control
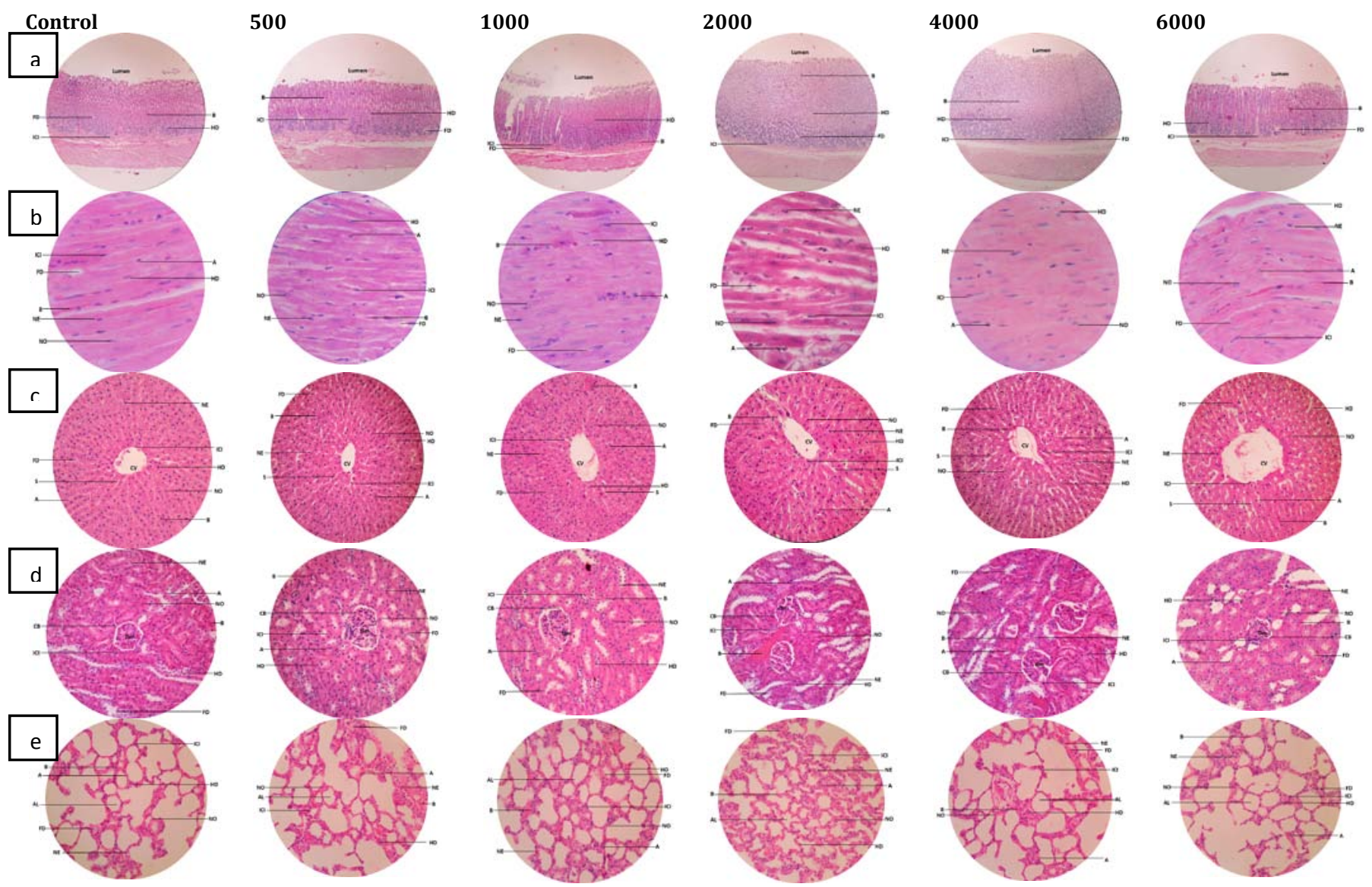

Fig. 1: Histology of control group and dose of $\beta$-chitin 500, 1000, 2000, 4000 and $6000 \mathrm{mg} / \mathrm{kg} B W$ with HE staining (A=Atrophy, $\mathrm{AL}=$ Alveolus, $\mathrm{B}=\mathrm{Bleeding}, \mathrm{CB}=\mathrm{Bowman}$ 's capsule, $\mathrm{CV}=$ Central Vein, $\mathrm{FD}=$ Fatty degeneration, $\mathrm{Gm}=\mathrm{Glomerulus,} \mathrm{HD}=\mathrm{Hydropic}$ degeneration, ICI= Inflammatory cell infiltration, NE=Necrosis, NO=Normal, S= Sinusoid). a) Stomach organ, obj., 10x, (b) Heart organ, obj., 100x, (c) Liver organ, obj., 40x, (d) Kidney organ, obj., 40x, (e) Lung organ, obj., 40x. All organs using ocular lens magnification 12x

\section{DISCUSSION}

There are several methods for testing acute toxicity, including traditional LD50, approved fixed-dose procedure (FDP), acute toxic class (ATC) method and up and down procedure (UDP) [15]. The acute toxicity test method of $\beta$-chitin in this study followed the acute toxic class method from the Organization for Economic Cooperation and Development (OECD) guidelines, where the highest dose to cause LD50 was $5000 \mathrm{mg} / \mathrm{kg}$. The advantages of the ATC method include the use of a small number of test animals, reproducible 
testing methods, and being able to see the level of toxicity the same as other procedures [16]. Acute toxicity testing does not need to be continued if the test animals can survive at doses above $5000 \mathrm{mg} / \mathrm{kg}$ [17]. Because chitin has safe properties [18], the highest dose used was $6000 \mathrm{mg} / \mathrm{kg}$ (more than $5000 \mathrm{mg} / \mathrm{kg}$ ) [15]. Giving the highest dose of $\beta$-chitin of $6000 \mathrm{mg} / \mathrm{kg}$ to mice did not show any behavioral changes such as changes in skin and fur color, eyes, backward walking behavior, tremor, convulsion, salivation, diarrhea, lethargy, sleep, and coma. No deaths were found up to a dose of $6000 \mathrm{mg} / \mathrm{kg}$ BW of chitin administration; from these results, $\beta$-chitin has practically non-toxic properties [12]. Table 1 shows a significant increase in the body weight of mice in all groups from day 1 to day 14. It shows that the administration of $\beta$-chitin did not reduce the appetite of the mice. The statistical test (table 2) showed that all the relative percentages of organ weight (stomach, heart, liver, kidneys, and lungs) were not significantly different compared to the control group. To ensure the state of the organs, then proceed with histopathological tests on all organs.

The number of normal cells at a dose of $6000 \mathrm{mg} / \mathrm{kg} \mathrm{BW}$ in all organs showed a significant decrease compared to the control group. An increase followed this in the number of necrotic cells. Although the liver, stomach and lungs have increased apoptotic cells, this is a normal process in every living organism. Apoptosis is a process of cell death that occurs naturally and is programmed. It is different from necrosis which occurs due to cell damage by pathogens or toxins [19]. Factors causing necrosis are caused by extreme physicochemical stress such as osmotic pressure, mechanical stress, heat, and freeze-thawing [20]. The high number of necrotic cells at a dose of $6000 \mathrm{mg} / \mathrm{kg} \mathrm{BW}$ probably occurs due to mechanical stress arising from the insoluble characteristics of chitin, so that chitin accumulates in organs and is difficult to excrete. It was found that the low solubility of a substance increases its toxicity [21]. Cell necrosis is characterized by loss of cell membrane integrity, cytoplasmic swelling, rounded cells [22]. From Tables 3 and 4, it can be seen that all doses of $\beta$-chitin in all organs did not show significant differences compared to the control group. It shows that although there was more necrosis than the control group, the administration of $\beta$-chitin had no significant impact on the qualitative observations. From fig. 1 it can be seen that there are significant differences in the liver and kidneys between the 6000 $\mathrm{mg} / \mathrm{kg}$ BW dose group and the control group in liver and kidney. These differences include the greatest CV widening in the liver and the appearance of the glomerulus in the kidney has an irregular shape and shrinks. Due to the lack of information about chitin, the cause of histopathological abnormalities in the liver, kidneys, and other organs is still unclear and requires further research.

\section{CONCLUSION}

Qualitative histopathological observations at the highest dose of $\beta$ chitin, although showed abnormalities of the liver and kidney compared to those of the control group, did not affect the organ function. This acute toxicity study reveals that $\beta$-chitin up to a dose of $6000 \mathrm{mg} / \mathrm{kg}$ of BW is not toxic, as proved by the normal behaviour, body weight, and vital organ weight of the animals. Further chronic toxicities study is needed to confirm its safety.

\section{ACKNOWLEDGEMENT}

The authors would like to thank the Rector of Universitas Padjadjaran (West Java, Indonesia) for funding the project and the publication fee via the Academic-Leadership Grant of the Directorate of Research and Community Engagement. The present work was conducted in the framework of the doctoral dissertation of the first author at the Faculty of Pharmacy, Universitas Padjadjaran, West Java, Indonesia.

\section{FUNDING}

The project is funded by Rector of Universitas Padjadjaran (West Java, Indonesia). The publication of the work is assisted with AcademicLeadership Grant of the Directorate of Research and Community Engagement.

\section{AUTHORS CONTRIBUTIONS}

All the authors contributed equally.

\section{CONFLICT OF INTERESTS}

Declared none

\section{REFERENCES}

1. Bouhenna M, Salah R, Bakour R, Drouiche N, Abdi N, Grib H, Lounici H, Mameri N. Effects of chitin and its derivatives on human cancer cells lines. Environ Sci Pollut Res Int. 2015;22(20):15579-86. doi: 10.1007/s11356-015-4712-3, PMID 26013739.

2. Salah R, Michaud P, Mati F, Harrat Z, Lounici H, Abdi N, Drouiche N, Mameri N. Anticancer activity of chemically prepared shrimp low molecular weight chitin evaluation with the human monocyte leukaemia cell line, THP-1. Int J Biol Macromol. 2013;52:333-9. doi: 10.1016/j.ijbiomac. 2012.10.009, PMID 23085488.

3. Bae MJ, Shin HS, Kim EK, Kim J, Shon DH. Oral administration of chitin and chitosan prevents peanut-induced anaphylaxis in a murine food allergy model. Int J Biol Macromol. 2013;61:164-8. doi: 10.1016/j.ijbiomac.2013.06.017, PMID 23806320.

4. Anandan R, Nair PGV, Mathew S. Anti-ulcerogenic effect of chitin and chitosan on mucosal antioxidant defence system in HCl-ethanol-induced ulcer in rats. J Pharm Pharmacol. 2004;56(2):265-9. doi: 10.1211/0022357023079, PMID 15005886 .

5. Amelia R, Saptarini NM, Halimah E, Andriani Y, Nurhasanah A, Levita J. Pharmacology activities and extraction of $\alpha$-chitin prepared from crustaceans: a review. J Appl Pharm Sci. 2020;10(12):140-9.

6. Amelia R, Indawati I, Saptarini NM, Levita J, Sumiwi SA. The proximate analysis and spectral profile of chitin extracted from the shell of Portunus pelagicus originated from Cirebon, Indonesia. Rasayan J Chem. 2021;14(3):1755-60. doi: 10.31788/RJC.2021.1436354.

7. Roy JC, Salaün F, Giraud S, Ferri A. Solubility of chitin: solvents, solution behaviors and their related mechanisms. In: Solubility of polysaccharides an; 2017. p. 109-26. doi:10.5772/intechopen.71385

8. Kumar PTS, Abhilash S, Manzoor K, Nair SV, Tamura H, Jayakumar R. Preparation and characterization of novel $\beta$ chitin/nanosilver composite scaffolds for wound dressing applications. Carbohydr Polym. 2010;80(3):761-7. doi: 10.1016/j.carbpol.2009.12.024.

9. PT SK, Lakshmanan VK, Raj M, Biswas R, Hiroshi T, Nair SV, Jayakumar R. Evaluation of wound healing potential of $\beta$-chitin hydrogel/nano zinc oxide composite bandage. Pharm Res. 2013;30(2):523-37. doi: 10.1007/s11095-012-0898-y, PMID 23135816.

10. Niho N, Tamura T, Toyoda K, Uneyama C, Shibutani M, Hirose M. A 13-week subchronic toxicity study of chitin in F344 rats. Kokuritsu Iyakuhin Shokuhin Eisei Kenkyusho Hokoku. 1999;117(117):129-34. PMID 10859946.

11. Huang WC, Zhao D, Guo N, Xue C, Mao X. Green and facile production of chitin from crustacean shells using a natural deep eutectic solvent. J Agric Food Chem. 2018;66(45):11897901. doi: 10.1021/acs.jafc.8b03847, PMID 30359004.

12. Pedoman Uji Toksisitas BPOM, Secara N. In vivo; 2014.

13. Sabbani V, Alluri R, Satla S. Acute oral toxicity studies of ethanol leaf extracts of derris scandens and pulicaria wightiana in albino rats. Int J Pharmacol Res. 2015;5(1):12-7.

14. Bagus I, Winaya O, Udayana U. Histopatologi ginjal tikus putih akibat Pemberian ekstrak Pegagan (Centella asiatica) peroral. Bul Vet Udayana. 2013;5(1):63-9.

15. Erhirhie EO, Ihekwereme CP, Ilodigwe EE. Advances in acute toxicity testing: strengths, weaknesses and regulatory acceptance. Interdiscip Toxicol. 2018;11(1):5-12. doi: 10.2478/intox-2018-0001, PMID 30181707.

16. OECD. Test No. 423: acute oral toxicity-acute toxic class method. OECD guideline test chem (Dec); 2002. p. 1-14.

17. K SN, Maheshwari DG. An overview toxic test methods. 2016;8(2):3834-49.

18. Bose I, Singh R, Negi P, Singh Y. Chitin as bio-based nanomaterial in packaging: a review. Mater Today Proc. 2021;46:11254-7. doi: 10.1016/j.matpr.2021.02.656. 
19. Peter ME. Programmed cell death: Apoptosis meets necrosis Nature. 2011;471(7338):310-2. doi: 10.1038/471310a, PMID 21412328.

20. Kaczmarek A, Vandenabeele P, Krysko DV. Necroptosis: the release of damage-associated molecular patterns and its physiological relevance. Immunity. 2013;38(2):209-23. doi: 10.1016/j.immuni.2013.02.003, PMID 23438821.
21. Peng G, Roberts JC. Solubility and toxicity of resin acids. Water Res. 2000;34(10):2779-85. doi: 10.1016/S0043-1354(99)00406-6.

22. Berghe Vanden T, Vanlangenakker N, Parthoens E, Deckers W, Devos M, Festjens N, Guerin CJ, Brunk UT, Declercq W, Vandenabeele P. Necroptosis, necrosis and secondary necrosis converge on similar cellular disintegration features. Cell Death Differ. 2010;17(6):922-30. doi: 10.1038/cdd.2009.184, PMID 20010783. 